\title{
Nitrogen Fixation by Marine Agar-degrading Bacteria
}

\author{
By WUNG YANG SHIEH, ${ }^{*}$ USIO SIMIDU ${ }^{1}$ AND \\ YOSHIHARU MARUYAMA \\ ${ }^{1}$ Ocean Research Institute, University of Tokyo, Nakano, Tokyo 164, Japan \\ ${ }^{2}$ Department of Agricultural Chemistry, Faculty of Agriculture, University of Tokyo, Bunkyo, \\ Tokyo 113, Japan
}

(Received 1 February 1988)

\begin{abstract}
Several strains of agar-degrading bacteria capable of fixing $\mathrm{N}_{2}$ were isolated from seawater and eelgrass-bed sediment in Aburatsubo Inlet, Kanagawa, Japan, during the summer of 1986. All strains were Gram-negative, facultatively anaerobic, and required $\mathrm{NaCl}$ for growth. They were straight or slightly curved rods and were motile in liquid medium by means of a single polar flagellum. These characteristics as well as the $G+C$ contents of their DNA $(44 \cdot 7-46 \cdot 1 \mathrm{~mol} \%)$ placed them in the family Vibrionaceae. These strains produced extracellular agarase on agar medium, yielding reducing sugars and acids as the end products. They expressed significant nitrogenase (acetylene reduction) activities after a few hours of incubation under anaerobic conditions. They utilized combined nitrogen sources both aerobically and anaerobically, but fixed $\mathrm{N}_{2}$ only under anaerobic conditions. Neither yeast extract nor vitamins were required for $\mathrm{N}_{2}$ fixation. These strains were demonstrated to fix $\mathrm{N}_{2}$ anaerobically using agar as the sole carbon source.
\end{abstract}

\section{INTRODUCTION}

Agar, a complex polysaccharide extracted from marine red algae, is widely employed as a gelling agent for microbiological culture media. It is attacked by only relatively few species of micro-organisms, including bacteria and actinomycetes (Breed et al., 1957). Most strains of agar-degrading bacteria have been isolated from marine sources, but there are reports that they also occur in fresh water, sewage and soil (Agbo \& Moss, 1979; v. Hofsten \& Malmqvist, 1975; van der Meulen et al., 1974). Although many agar-degrading strains have been reported in the literature, Bergey's Manual of Systematic Bacteriology (Krieg, 1984) retains only a few described species.

$\mathrm{N}_{2}$ fixation, like agar degradation, is a property found only among prokaryotic organisms. Heterotrophic $\mathrm{N}_{2}$-fixing bacteria require a variety of sugars and organic acids such as glucose, sucrose, mannitol, malate, pyruvate and lactate as carbon sources for the enhancement of heterotrophic $\mathbf{N}_{2}$ fixation. A cellulolytic $\mathbf{N}_{2}$-fixing bacterium has been isolated from the gland of Deshayes in six species of marine shipworms (Waterbury et al.,1983). This bacterium was able to grow on a $\mathrm{N}$-free medium using cellulose as the sole carbon source under microaerophilic conditions. However, there are no reports that heterotrophic bacteria fix $\mathrm{N}_{2}$ utilizing other refractory organic compounds like agar as the sole carbon source.

During a study of marine $\mathrm{N}_{2}$ fixation, we isolated several halophilic bacteria from seawater and eelgrass-bed sediment in a small inlet located in Kanagawa, Japan. These organisms were effective not only in degrading agar but also in fixing $\mathrm{N}_{2}$. The present paper describes the isolation and characterization of these organisms, and the properties of their $\mathrm{N}_{2}$ fixation.

Abbreviation: PHB, poly- $\beta$-hydroxybutyrate.

0001-4675 (C) 1988 SGM 


\section{METHODS}

Media. The liquid $\mathrm{N}$-free medium used for the enrichment of $\mathrm{N}_{2}$-fixing bacteria contained the following components: (i) basal medium $\left(\mathrm{NaCl}, 28 \mathrm{~g} ; \mathrm{MgSO}_{4} .7 \mathrm{H}_{2} \mathrm{O}, 5 \mathrm{~g} ; \mathrm{Na}_{2} \mathrm{MoO}_{4} .2 \mathrm{H}_{2} \mathrm{O}, 10 \mathrm{mg} ; \mathrm{CaCl}_{2} .2 \mathrm{H}_{2} \mathrm{O}, 10 \mathrm{mg}\right.$; Tris, $50 \mathrm{mmol}$; distilled water, $800 \mathrm{ml}$ ) adjusted to $\mathrm{pH} 8 \cdot 0$; (ii) $\mathrm{K}_{2} \mathrm{HPO}_{4}, 0.5 \mathrm{~g}$; distilled water, $100 \mathrm{ml}$; (iii) glucose, $5 \mathrm{~g} ; \mathrm{FeCl}_{3} \cdot 6 \mathrm{H}_{2} \mathrm{O}, 15 \mathrm{mg}$; distilled water, $100 \mathrm{ml}$. These solutions were mixed after autoclaving separately. The PY broth medium contained $2.0 \mathrm{~g}$ Polypepton (Daigo, Tokyo, Japan) and $0.5 \mathrm{~g}$ yeast extract (Difco) in $11\left(15 \mathrm{~g} \mathrm{l}^{-1}\right)$ $90 \%$ seawater. The $\mathrm{pH}$ was adjusted to 7.6. Agar (Difco, $15 \mathrm{~g} \mathrm{l}^{-1}$ ) was added to this medium for the preparation of plating medium. Two semi-solid media were used for the measurement of agarase activity. A PY semi-solid medium was made by supplementing PY broth medium with $50 \mathrm{mmol}$ Tris and $2 \mathrm{~g}$ agar (Difco) $\mathrm{l}^{-1}$, and a mineral semi-solid medium was prepared which contained $1 \mathrm{mmol} \mathrm{NH}_{4} \mathrm{NO}_{3}, 2 \mathrm{~g}$ agar (Difco), and $50 \mathrm{mmol}$ Tris in 11 $90 \%$ seawater. Both of the semi-solid media were adjusted to $\mathrm{pH} 8.0$ before autoclaving.

Isolation. Samples of seawater and eelgrass (Zostera marina) bed sediment were collected in Aburatsubo Inlet, Kanagawa, Japan, during the summer of 1986 . A $1 \mathrm{ml}$ or $1 \mathrm{~g}$ wet weight sub-sample was serially diluted with $9 \mathrm{ml}$ sterile seawater. A $1 \mathrm{ml}$ volume of each dilution was then transferred to a $20 \mathrm{ml}$ culture tube containing $5 \mathrm{ml}$ liquid $\mathrm{N}$-free medium. After sealing with a rubber stopper, the air in the culture tube was replaced with $\mathrm{N}_{2}$ gas. The cultures were incubated at $25^{\circ} \mathrm{C}$ in the dark for 3-7 d. Cultures that developed visible turbidity were again serially diluted $(0 \cdot 1 \mathrm{ml}$ of each dilution being transferred to fresh liquid $\mathrm{N}$-free medium) and the anaerobic enrichment procedure described above was repeated. The culture of the highest dilution with positive growth from the second enrichment was spread on PY agar plates, and the plates were incubated at $25^{\circ} \mathrm{C}$ for $2-3 \mathrm{~d}$ under aerobic conditions. Some colonies which caused liquefaction or depressions in plates were picked off and purified by successive streaking on PY agar plates. The nitrogenase activities of the isolates were confirmed by acetylenereduction assay methods. Five agar-degrading strains which expressed nitrogenase activity were used in the present study. One strain, isolated from seawater, was named FA13, and the other four strains, isolated from sediment, were designated as SAE1, SAE2, SMT,5 and SFG5.

Characterization of the agar-degrading strains. This was done as described in our previous report (Shieh et al., 1987) with several modifications. The ability to ferment different carbohydrates was determined in modified PY broth media containing $15 \mathrm{ml} 0 \cdot 2 \%(\mathrm{w} / \mathrm{v})$ bromothymol blue $\mathrm{l}^{-1}$ and $10 \mathrm{~g}$ of the test carbohydrate $\mathrm{l}^{-1}$. Agar was not added to these media because the strains produced acid from agar. The cultures were incubated under anaerobic conditions using a GasPak Anaerobic System (BBL), and examined for colour changes after $7 \mathrm{~d}$ incubation. PHB (poly- $\beta$-hydroxybutyrate) accumulation was tested in a liquid medium containing: (i) yeast extract (Difco), $0 \cdot 2 \mathrm{~g}$; Tris, $50 \mathrm{mmol}$; seawater, $900 \mathrm{ml}$; adjusted to $\mathrm{pH} 8.0$; (ii) glucose, $5.0 \mathrm{~g}$; distilled water, $100 \mathrm{ml}$. The two solutions were mixed after autoclaving separately. Strain RSI19 (Shieh et al., 1987) and the type strain of Vibrio nereis (ATCC 25917) were used as standards for the observation of PHB accumulation. Growth at different concentrations of $\mathrm{NaCl}$ was determined in yeast extract $(0.4 \%, \mathrm{w} / \mathrm{v})$ broth containing $0,1,3,6$ and $8 \% \mathrm{NaCl}$. Compounds which could serve as sole carbon sources were determined in modified liquid $\mathrm{N}$-free media containing $0.2 \%(\mathrm{w} / \mathrm{v})$ of the carbon source in the place of glucose and supplemented with $2 \mathrm{mmol} \mathrm{NH}_{4} \mathrm{Cl}^{-1}$.

DNA base composition. Bacterial DNA was extracted and purified by the method of Marmur (1961) with some modifications. The purified DNA was hydrolysed into nucleotides with nuclease P1 and then the mixture of nucleotides was used for determination of the G+C content by HPLC as described previously (Shieh et al., 1987).

Determination of agarase activity. The strains were inoculated into $32 \mathrm{ml}$ test tubes containing $5 \mathrm{ml}$ of PY or mineral semi-solid medium and incubated at $25^{\circ} \mathrm{C}$ for $1 \mathrm{~d}$ under aerobic conditions. The formation of reducing sugars was determined with 3,5-dinitrosalicylic acid (DNS) reagent (von Borel et al., 1952), and results expressed as galactose equivalents.

Measurement of nitrogenase activity. The acetylene-reduction assay method using a Shimadzu G-4CM gas chromatograph was employed (Shieh et al., 1987). Specific nitrogenase activities were calculated over $4 \mathrm{~h}$ periods (4-8 or 8-12 h) of incubation. No growth occurred during the period when nitrogenase activity was measured.

Growth studies. The liquid N-free medium and its modified media were used for the growth studies, in which specific growth rates were calculated from changes in $\mathrm{OD}_{600}$ with time.

\section{RESULTS AND DISCUSSION}

\section{Characterization of strains}

The $\mathrm{N}_{2}$-fixing strains studied produced round, non-pigmented colonies surrounded by distinct depressions on PY agar plates after 2-3d incubation. When such plates were flooded with iodine/potassium iodide solution, clear yellow haloes formed around the colonies in contrast to the purple-brown background. This indicates that agarase diffused out from the colonies and reducing compounds were released during agar degradation. All five strains required $\mathrm{NaCl}$ for growth, and fermented glucose with the production of acid but no gas. They 
Table 1. Physiological and biochemical characteristics of the five agar-degrading $\mathrm{N}_{2}$-fixing strains

\begin{tabular}{|c|c|c|c|}
\hline Characteristic & Reaction* & Characteristic & Reaction* \\
\hline Glucose fermentation & + & Agarase & + \\
\hline Gas from glucose & - & Amylase & $\mathbf{w}$ \\
\hline Pigmentation & - & Lecithinase & - \\
\hline Oxidase & - or $w$ & Chitinase & - \\
\hline Catalase & $\mathrm{v}$ & Hydrolysis of: & \\
\hline Nitrogenase & + & Tween 80 & + \\
\hline PHB accumulation & $\mathbf{a}$ & Casein & - \\
\hline Sensitivity to & & Fermentation of: & \\
\hline $\mathrm{O} / 129(150 \mu \mathrm{g})$ & - & Galactose & + \\
\hline Luminescence (at $20^{\circ} \mathrm{C}$ ) & - & Mannose & + \\
\hline Swarming & - & Sucrose & - \\
\hline Growth at: & & Lactose & $v$ \\
\hline $4^{\circ} \mathrm{C}$ & $\mathbf{v}$ & Xylose & + \\
\hline $20^{\circ} \mathrm{C}$ & + & Cellobiose & + \\
\hline $35^{\circ} \mathrm{C}$ & + & Melibiose & + \\
\hline $40^{\circ} \mathrm{C}$ & - or $w$ & D-Arabinose & - \\
\hline Growth in: & & L-Arabinose & $\mathrm{v}$ \\
\hline $0 \% \mathrm{NaCl}$ & - & L-Rhamnose & - \\
\hline $1 \% \mathrm{NaCl}$ & + & Inositol & - \\
\hline $6 \% \mathrm{NaCl}$ & + & Mannitol & + \\
\hline $8 \% \mathrm{NaCl}$ & - & Sorbitol & + \\
\hline Arginine dihydrolase & - & Glycerin & - \\
\hline Lysine decarboxylase & - & Salicin & - \\
\hline Ornithine decarboxylase & - & Starch & + \\
\hline Deoxyribonuclease & - or $w$ & Agar & + \\
\hline Gelatinase & + or $w$ & & \\
\hline
\end{tabular}

Table 2. Ability of the five agar-degrading, $\mathrm{N}_{2}$-fixing strains to utilize compounds as sole carbon and energy sources

\section{Compound}

Citrate

Acetate

Malonate

D-Tartrate

L-Threonine

L-Lysine

Putrescine

Fumarate

DL-Alanine

L-Arginine

Glycine

Glycolate

Glycerin

Salicin

Dulcitol

$\beta$-Hydroxybutyrate Inositol

Compound
Glucose
Mannose
Galactose
Melibiose
Lactose
Laevulose
Xylose
Mannitol
Sorbitol
D-Arabinose
L-Arabinose
L-Rhamnose
Cellobiose
Starch
Inulin
Agar
Methanol

Methanol
Utilization*

+
- or w
-
-
$\mathrm{v}$
-
-
+
+
+ or $w$

-

$+$

$+$

$-$

$-$

* + , positive; - , negative; $w$, weak positive; $v$, variable between strains.

were Gram-negative, straight or slightly curved rods that were motile by means of a single polar flagellum when grown in PY liquid medium. The $\mathrm{G}+\mathrm{C}$ contents of their DNA ranged from $44 \cdot 7 \pm 0 \cdot 1$ to $46 \cdot 1 \pm 0 \cdot 2 \mathrm{~mol} \%$. These characteristics are sufficient to place all these strains in the family Vibrionaceae. Additional physiological and biochemical characteristics of these strains are summarized in Table 1, and the various compounds which were used as sole sources 
of carbon and energy are presented in Table 2. The strains might be members of the genus Vibrio but not Photobacterium because they could utilize mannitol (Table 2). However, further studies are needed to establish their exact taxonomic position because they were not sensitive to $\mathrm{O} / 129$ (Donovan \& Furniss, 1984), and their ability to accumulate PHB was ambiguous; although some granule-like materials appeared in the cells, they were apparently different from the PHB granules which accumulated in the cells of strains RSI19 and ATCC 25917. Several $\mathrm{N}_{2}$-fixing bacteria belonging to the genus Vibrio have been described, but none of them have the ability to degrade agar (Guerinot et al., 1982; Shieh et al., 1987; West et al., 1985). All the other recognized species of the family Vibrionaceae also lack agarase activity. Many aerobic agarolytic bacteria previously placed in the genus Vibrio (Breed et al., 1957) are no longer accepted as belonging to the currently recognized family Vibrionaceae (Krieg, 1984), which consists only of facultatively anaerobic bacteria.

\section{Agarase activity}

The agarase activity of the strains ranged from 32 to $52 \mu \mathrm{g}$ galactose $\mathrm{ml}^{-1} \mathrm{~d}^{-1}$ in the mineral semi-solid medium and from 35 to $74 \mu \mathrm{g}$ galactose $\mathrm{ml}^{-1} \mathrm{~d}^{-1}$ in the PY semi-solid medium. However, the actual agarase activities were probably higher than the detected values, since these strains might have fermented and/or utilized galactose (Tables 1 and 2) formed during agar degradation.

\section{Nitrogenase activity and growth}

The nitrogenase activities of the strains ranged from $50 \pm 10$ to $91 \pm 8 \mathrm{nmol} \mathrm{C}_{2} \mathrm{H}_{4}$ (mg dry wt cells $)^{-1} \mathrm{~h}^{-1}$ under $\mathrm{Ar} / \mathrm{C}_{2} \mathrm{H}_{2}(90: 10, \mathrm{v} / \mathrm{v})$. Lowering the $\mathrm{pH}$ of the medium from 8 to 6 resulted in a decrease of activity of about $50-70 \%$. The strains showed significant growth in liquid $\mathrm{N}$-free medium under $\mathrm{N}_{2}$, indicating that they utilized $\mathrm{N}_{2}$ as the sole nitrogen source anaerobically. Under these conditions, their specific growth rates ranged from 0.12 to $0.21 \mathrm{~h}^{-1}$ during the exponential phase of growth. No growth occurred in this medium aerobically. Combined nitrogen sources such as Tryptone (Difco, $\left.1 \mathrm{~g} \mathrm{l}^{-1}\right), \mathrm{NH}_{4} \mathrm{Cl}(2 \mathrm{mM})$ and $\mathrm{KNO}_{3}(2 \mathrm{~mm})$ added to the liquid $\mathrm{N}$-free medium increased specific growth rates $1 \cdot 6-$ to $6 \cdot 3$-fold both aerobically and anaerobically under Ar. The above results indicate that the strains are facultatively anaerobic, $\mathrm{N}_{2}$-fixing bacteria. The bacterial growth in liquid $\mathrm{N}$-free medium under $\mathrm{N}_{2}$ never developed an $\mathrm{OD}_{600}$ higher than 0.5 during the stationary phase, and growth was accompanied by a fall in the $\mathrm{pH}$ of the medium. The $\mathrm{pH}$ decrease was large during the late-exponential phase of growth $(>2 \mathrm{pH}$ units), indicating that the strains fermented glucose and large amounts of organic acids were excreted into the medium. This might have limited the maximal growth level. When the strains were inoculated into the $\mathrm{N}$-free stab medium which contained $0.5 \%$ agar (Difco) instead of glucose as the sole carbon source and incubated aerobically, stratified bacterial growth appeared about 0.5 to $1.0 \mathrm{~cm}$ below the agar surface after several days of incubation. This shows that agar served as the sole source of carbon and energy for anaerobic $\mathrm{N}_{2}$ fixation of these strains. The agar of the stab cultures was completely liquefied after incubation for 1 to 2 months.

Guerinot \& Colwell (1985) studied marine $\mathrm{N}_{2}$-fixing bacteria and stated that yeast extract and vitamins enhanced nitrogenase activity. Some terrestrial $\mathrm{N}_{2}$-fixing bacteria also require vitamins or combined nitrogen for nitrogenase activity (Lindberg \& Granhall, 1984; Watanabe $\&$ Barraquio, 1979). The present strains, however, had no special nutritional requirements. They grew and expressed nitrogenase activity in liquid $\mathrm{N}$-free medium containing neither yeast extract nor vitamins. These properties are advantageous in allowing them to live in nutrientlimited natural marine environments.

Marine agar-degrading bacteria play an important role in the recycling of organic matter in coastal environments where agar forms a significant constituent of polysaccharides from red algae. The fixation of $\mathrm{N}_{2}$ by the present strains suggests that marine agar-degrading bacteria may also be important in providing inputs of ammonium nitrogen into marine environments, especially in sediments where combined nitrogen is usually limited and anaerobic conditions easily occur.

The authors are grateful to Ms K. Kita-Tsukamoto, Ocean Research Institute, University of Tokyo, for her advice in determining the $\mathrm{G}+\mathrm{C}$ content of DNA. 


\section{REFERENCES}

AgBo, J. A. C. \& Moss, M. O. (1979). The isolation and characterization of agarolytic bacteria from a lowland river. Journal of General Microbiology 115, 355368.

von Borel, E., Hostettler, F. \& Deuel, H. (1952). Fasciculus I-15. Quantitative Zuckerbestimmung mit 3,5-Dinitrosalicylsäure und Phenol. Helvetica chimica acta 35, 115-120.

Breed, R. S., Murray, E. G. D. \& SMith, N. R. (1957). Bergey's Manual of Determinative Bacteriology, 7th edn. Baltimore: Williams \& Wilkins.

Donovan, T. J. \& Furniss, A. L. (1984). Vibrios, Aeromonas, Plesiomonas, and Photobacterium. In Microbiological Methods, 5th edn, pp. 271-279. Edited by C. H. Collins \& P. M. Lyne. London: Butterworth.

GUERINOT, M. L. \& Colwell, R. R. (1985). Enumeration, isolation, and characterization of $\mathrm{N}_{2}$-fixing bacteria from seawater. Applied and Environmental Microbiology 50, 350-355.

Guerinot, M. L., West, P. A., Lee, J. V.\& Col Well, R. R. (1982). Vibrio diazotrophicus sp. nov., a marine nitrogen-fixing bacterium. International Journal of Systematic Bacteriology 32, 350-357.

v. Hofsten, B. \& MalmQvist, M. (1975). Degradation of agar by a Gram-negative bacterium. Journal of General Microbiology 87, 150-158.

KRIEG, N. R. (editor) (1984). Bergey's Manual of Systematic Bacteriology, vol. 1. Baltimore: Williams \& Wilkins.
LindBerG, T. \& Granhall, U. (1984). Isolation and characterization of dinitrogen-fixing bacteria from the rhizosphere of temperate cereals and forage grasses. Applied and Environmental Microbiology 48, 683-689.

MARmuR, J. (1961). A procedure for the isolation of deoxyribonucleic acid from microorganisms. Journal of Molecular Biology 3, 208-218.

VAN DER MEUlen, H. J., HaRder, W. \& VeldKamp, H. (1974). Isolation and characterization of Cytophaga flevensis sp. nov., a new agarolytic flexibacterium. Antonie van Leeuwenhoek 40, 329-346.

Shieh, W. Y., Simidu, U. \& Maruyama, Y. (1987). Isolation of a nitrogen-fixing Vibrio species from the roots of eelgrass (Zostera marina). Journal of General and Applied Microbiology 33, 321-330.

WATANABE, I. \& BarRaQuio, W. L. (1979). Low levels of fixed nitrogen required for isolation of free-living $\mathrm{N}_{2}$-fixing organisms from rice roots. Nature, London 277, 565-566.

Waterbury, J. B., Calloway, C. B. \& Turner, R. D. (1983). A cellulolytic nitrogen-fixing bacterium cultured from the gland of Deshayes in shipworms (Bivalvia: Teredinidae). Science 221, 1401-1403.

West, P. A., Brayton, P. R., Twilley, R. R., Bryant, T. N. \& Colwell, R. R. (1985). Numerical taxonomy of nitrogen-fixing 'decarboxylasenegative' Vibrio species isolated from aquatic environments. International Journal of Systematic Bacteriology 35, 198-205. 